Historic, Archive Document

Do not assume content reflects current scientific knowledge, policies, or practices. 



\section{PRICE LIST OF CHOICE}

\section{GLADIOLUS BULBS}

Grown By

\section{T. R. FERRIS}

\section{HUNTLEY, McHENRY CO., ILLINOIS}

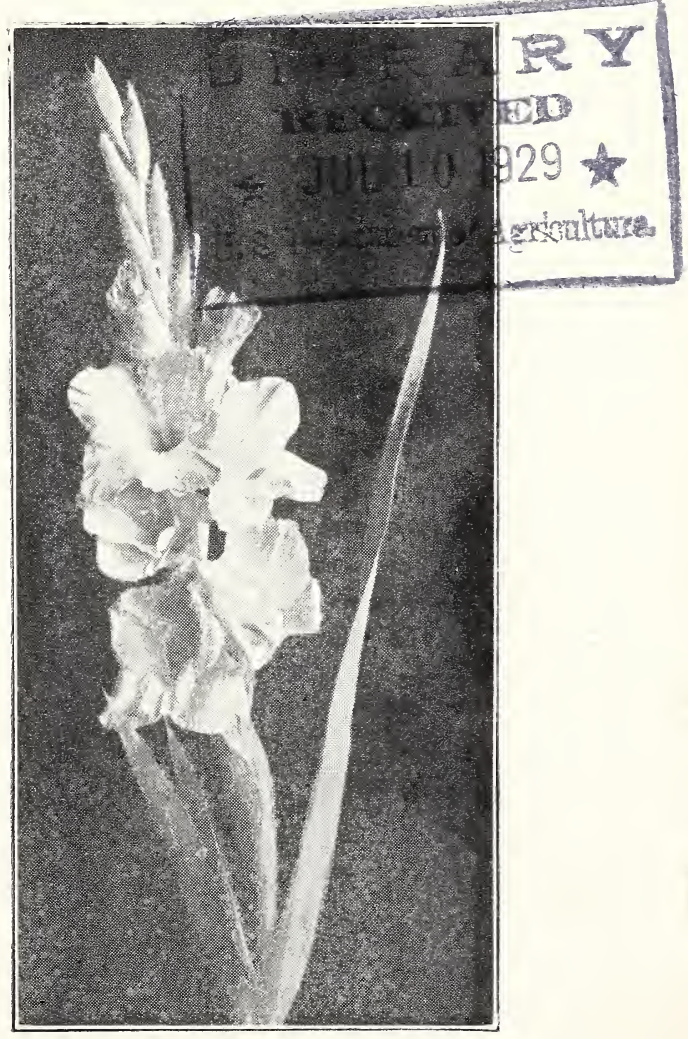

Lady Elgin, Originated by T. R. Ferris 


\section{GLADIOLUS CULTURE}

Spade or plough the ground ten inches deep, then apply well rotted barnyard manure or pulverized sheep manure, working it into the soil with a hand rake.

Plant in rows eighteen or twenty inches apart, make a trench five inches deep, and place the bulbs two or three inches apart, in the trench and cover level full.

Plant in the spring, in May. Do not plant near trees or buildings.

\section{CULTIVATION}

Keep the soil loose by frequent hoeing, do not permit the ground to become crusted or hard, water when needed, not sprinkled, but water sufficient to reach the bulbs that are five inches below the top, then watch them grow and bloom.

\section{CARE OF BULBS}

Dig in the fall, about October or November, but do not delay long enough for the frost to reach them. Cut the stem off close to the bulb, dry in the sun a few days, then remove the old bulb that is attached to the bottom of the new bulb. Store in a dry cool place, free from frost.

TERMS-Price per doz. includes Parcel Post charges. One half doz. at the dozen rate. No order for less than $\$ 1.00$.

Cash with order or before shipment.

Bulbs are all first-class in every way. I sell only those grown by myself. All orders, large or small will receive my personal attention.

T. R. FERRIS, GLADIOLUS GROWER Huntley, Illinois 


\section{CHOICE GLADIOLUS BULBS}

ANNA EBERIUS, (Diener)-Dark velvety purple, throat deeper shade; flowers of large size.

A wonderful color............... Each 15c, Dozen $\$ 1.50$

ANTHONY B. KUNDERD, (Kunderd)-Tall, large, intensely ruffled flower of delicate deep cream color, overspread finest blush pink, winner of many awards........... Each 30c, Dozen $\$ 3.00$

BYRON L. SMITH, (Kunderd)-One of the very best. Most refined lavender pink on white ground. Color equal to a very choice orchid,

Each 15, Dozen \$1.50

CAROLINE ESBERG, (Diener)-Flame scarlet without any markings, Most vivid glossy red imaginable. The color of this variety does not fade under any condition.

Each \$2.00, Dozen $\$ 20.00$

CHARM, (Kunderd)-Pure deep rose-pink, a perfect blotch of deep red on lower petals, nicely ruffled....................... 50 ch

CLARAMOUNT, (Salbach)-Beautiful, clear, light yellow, shading to deep rich yellow in throat, strong flower spike. Blooms well placed and many open at a time.............. Each $\$ 1.00$

CRIMSON GLOW, (Betcher)-Perfect crimson, very large open flower on tall stiff spike. One of the very best reds........... Each $10 \mathrm{c}$, Dozen $\$ 1.00$

\section{DIENERS AMERICAN BEAUTY, (Diener)-} Brilliant American Beauty color. Throat creamy yellow striped with ruby, one spike opening a large number of flowers at one time forms an immense bouquet. Large flowers. Each $35 \mathrm{c}$, Dozen $\$ 3.50$

DON JUAN, (Kunderd)-Very large, strong plant with extra fine, pure salmon rose flowers of almost same color as Marshal Foch, but very beautifully ruffled............................. $\$ 1.00$

DR. ELKINS, (Kunderd) - White with lilac blue blotch. A sport from Mrs. F. Pendleton, and a rare beauty.......................................... $\$ 1.25$

DAVID STARR JORDAN, (Diener)-Immense flame colored, overlaid with scarlet. Lip mottled with cream. Flowers are very open like Amaryllis, with fine strong upright stems.

Each $15 \mathrm{c}$, Dozen $\$ 1.50$ 
E. J. SHAYLOR, (Kunderd) - Tall, very strong plant and large blooms. A beautiful pure deep rose pink. A prize winner.

Each 10c, Dozen \$1.00

ELORA, (Burbank)-Creamy white with rich cream throat on lower petals overlaid with dainty featherings of pink.... Each $15 \mathrm{c}$, Dozen $\$ 1.50$

EMILIE ASH, (Diener)-Creamy white, small cerise blotches in lower petals, one of the very best ruffled varieties.... Each $20 \mathrm{c}$, Dozen $\$ 2.00$

EUROPA,-Pure white, no markings, nearly all the blooms opened at a time, the best white. Each $10 \mathrm{c}$, Dozen $\$ 1.00$

EVELYN WIRTLAND, (Austin)-Beautiful shade of pink, darker at the edges, shell pink at center, scarlet blotches on lower petals.

Each $10 \mathrm{c}$, Dozen $\$ 1.00$

FLORA, (Velthuys)-Rich yellow, nearly all self color except for a few tiny markings in throat......................................... Dach $10 \mathrm{c}$, Dozen $\$ 1.00$

GERALDINE FARRAR, (Diener) -Pale lavender -violet with deep violet spot on the lip. Unlike other blue varieties, the growth is very strong and vigorous. This variety has made a big impression and was awarded first prize for the finest blue variety.......................... $\$ 10.00$

GLENDALE, (Davis)-An entirely new shade in gladioli, A beautiful dark magenta, no markings, Wide open flowers on tall straight spike.................................. Dach 35cen $\$ 3.50$

GLORY, (Kunderd)-Amber yellow suffused light rose, the original ruffled gladiolus......... Each 10c, Dozen 75 c

GOLDEN MEASURE,-Magnificent yellow, clear and bright, large wide open flowers, plain petals, and strong grower...Each $20 \mathrm{c}$, Dozen $\$ 2.00$ HEART OF JUANITA, (Diener)-Deep cherry scarlet. A very beautiful variety that does not fade in the sunlight. One of the best dark colored varieties....... Each $25 \mathrm{c}$, Dozen $\$ 2.50$ HERADA, (Austin) - Very large blooms of pure mauve, glistening and clear, unusually striking and attractive......................... $10 \mathrm{c}$, Dozen $\$ 1.00$

JACK LONDON, (Diener) - Light salmon with 'brilliant orange flame stripes, golden yellow throat with ruby striped center.

Each $15 \mathrm{c}$, Dozen $\$ 1.50$

LIEBESFEUER, - Intense scarlet, clear and beautiful, A gem......................... Dach 15c, Dozen $\$ 1.50$ 
LILLIAN HARRIS COFFIN, (Diener) - Shrimp pink overlaid with peach, lower peta!s lemon yellow with dashes of ruby, nice long spikes.

Withdrawn to increase stock.

LADY ELGIN, (Ferris) —Clear bright rose pink, shading to darker on lower petals, lighter in upper throat, nearly a self color. Ruffled edges. Four to six wide open flowers open at a time. See cut......... Each \$1.00, Dozen \$10.00

LE MARECHAL FOCH, (Duersen)-A Holland variety, Large lavender pink flowers, a shade brighter than America, good cut flower variety.................................. Dach $10 \mathrm{c}$, Dozen

LONDON SMOKE, (Diener)-Smoky pink overlaid with deep slate, A perfect grower and very odd variety.................... Each $25 \mathrm{c}$, Dozen $\$ 2.50$

LOVELINESS,-Creamy white tinted pale salmon, strong robust grower, very fine.............

Each $10 \mathrm{c}$, Dozen $\$ 1.00$

MARSHAL FOCH, (Kunderd)-Color of finest salmon pink, almost self color.

Each 25c, Dozen $\$ 2.50$

MARY FENNELL, (Kunderd)-Beautiful light lavender, lower petals primrose yellow, A delicate and beautiful coloring Each 10c, Dozen \$1.00

MARY PICKFORD, (Kunderd)-Creamy white blending to soft yellow in throat.

Each $15 \mathrm{c}$, Dozen $\$ 1.50$

MOTTLED BEAUTY, (Kunderd)-Extra large, well ruffled bloom, mottled and flaked with large and beautifully penciled blotches in

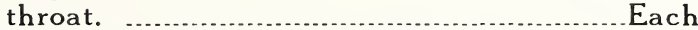

MRS. MARY STEARNS BURKE, (Diener)-Canary yellow overlaid with apricot and tinged rose, deep canary center with ruby throat....

Each 20c, Dozen $\$ 2.00$

MRS. DR. NORTON, (Kunderd)-White, edges of petals suffused La France pink, sulphur yellow blotch, extra choice..Each $15 \mathrm{c}$, Dozen $\$ 1.50$

MRS. WM. KENT, (Diener) - Light fawn to light ashes of roses in throat...... Each $10 \mathrm{c}$, Dozen $\$ 1.00$ MRS. FRANK PENDLETON, (Kunderd)-Rosy pink with a large ox-blood red blotch on lower petals..................................... $10 \mathrm{ch}$, Dozen $75 \mathrm{c}$

MRS. H. E. BOTHIN, (Diener) - Light geranium pink, heavily ruffled. Flame scarlet center, One of the loveliest combinations in Gladioli. Each 15c, Dozen $\$ 1.50$ 
MiRS. JOHN R. WALSH, (Diener)-Heavily ruffled, flesh pink, Three lower petals of flame shading into dark ruby at the throat, Flowers are very large. Should be in every collection Each 50c, Dozen $\$ 5.00$

MRS. LEON DOUGLAS, (Diener)-Ground color begonia rose striped with flame and brilliant scarlet. Lip pale lemon slightly speckled with ruby, the size of the flowers, we believe, is the largest in existence, and all are very open and well set on long spikes. One of our finest varieties... Each 75 c, Dozen $\$ 7.50$ MRS. RICHARD LOHRMAN, (Diener)-Creamy shell pink with pale yellow lip, A color rivaling the finest orchid. Flowers are very large and edges heavily ruffled. A variety of indescribable beauty............... Each 75c, Dozen $\$ 7.50$

MRS. F. C. PETERS, (Fischer)-A beautiful shade of rose lilac, with crimson blotch, white on lower petals, orchid coloring. Flowers are large and many open at a time. This we believe to be the best Glad of its coloring.

Each 50c, Dozen $\$ 5.00$

MRS. NEWAL VANDERBILT, (Diener)-Light salmon pink, heavily ruffled, Throat sulphur yellow, mottled and striped with crimson. Large flowers........................... 35 ch Dozen $\$ 3.50$ MYRTLE, (Kunderd)-Delicate shell pink shadEach 10c, Dozen $\$ 1.00$ ing to a cream throat. Medium early.

POLA NEGRI, (Diener) -Apricot with yellow lip. Ruffled, shading into old rose and salmon on the outer edges. One of the loveliest color combinations ever seen......................

Each $50 \mathrm{c}$, Dozen $\$ 5.00$

PINK CLOUD, (Kunderd)-A large distinct showy variety usually seven to nine beautiful soft rose pink blossoms open at a time, deeper rose throat........................................ $\$ 2.00$ PINK PERFECTION,-A remarkable variety, lovely light pink, very large wide open blooms, Flower stock sometimes comes crooked.

Each 10c, Dozen $\$ 1.00$

PRINCE OF WALES, - A rare and delicate salmon pink, a variety of lasting merit, Early bloomer................................. Each 10c, Dozen $\$ 1.00$ ROSE ASH, (Diener)-Ashes of roses, a decidedly new color in Gladioli, This variety is greatly admired.................... Each 15c, Dozen $\$ 1.50$ 
ROSE GLORY, (Kunderd) - A large and beautiful ruffled variety, of purest rose pink, deeper in throat............................. 20ach , Dozen \$2.00

RICHARD DIENER, (Diener)-Pure geranium pink with a slight sprinkling of ruby on creamy yellow center, Large flaring blossoms, rivaling an orchid in beauty. This variety has created a sensation wherever shown.

Each 75 c, Dozen $\$ 7.50$

SALOME JANE, (Diener)-Geranium p:nk, lower petals scarlet spotted with deep ruby. Flowers very large; a beauty

Each $35 \mathrm{c}$, Dozen $\$ 3.50$

SIDNEY PLUMMER, (Salbach)-Beautiful soft yellow, suffused delicate pink. Rich amber lip, amaranth purple tongue, An exquisite color combination. Blooms large, well placed, and slightly ruffled...............Each $35 \mathrm{c}$, Dozen $\$ 3.50$ SULPHUR GLOW, (Kunderd)-A beautiful shade of yellow. Nany well expanded intensely ruffled flowers open at a time.

Each $35 \mathrm{c}$, Dozen $\$ 3.50$

THOS. T. KENT, (Diener)-Rose-pink with ruby running through center of each petal. Many blooms open at a time, large flowers. Each 15c, Dozen $\$ 1.50$

TWILIGHT, (Kunderd)-Beautifully blushed creamy buff with throat of grandest yellow and pink, well ruffled.........Each 35c, Dozen $\$ 3.50$

VIRGINIA HALE, (Kunderd)-Beautiful soft creamy salmon rose, deeper towards border of all petals. Very refined and beautiful variety..................................... 40 cho

\section{PRIMULINUS HYBRIDS}

ALICE TIPLADY, (Kunderd)-The flowers are large and the color is a lovely combination of coppery bronze and orange..Each 10c, Dozen $\$ 1.00$

GOLD DROP, (Kunderd)-Extra large pure deep golden yellow, with beautiful red lines on petals. Ruffled............... Each 20c, Dozen $\$ 2.00$

MYRA, (Kunderd)-Deep salmon over yellow ground, yellow throat with pink lines. Large flowers and very beautiful.....Each 15c, Dozen $\$ 1.50$

TWINKLES, (Kunderd)-Flower is finest shade of salmon rose, throat of lighter color. Extra choice............................... 25ach

WANETA, (Kunderd)-Good size well opened flowers of splendid shade of rose pink, with throat of pure cream white. Ruffled. A choice variety....................Each 25c, Dozen $\$ 2.50$ 


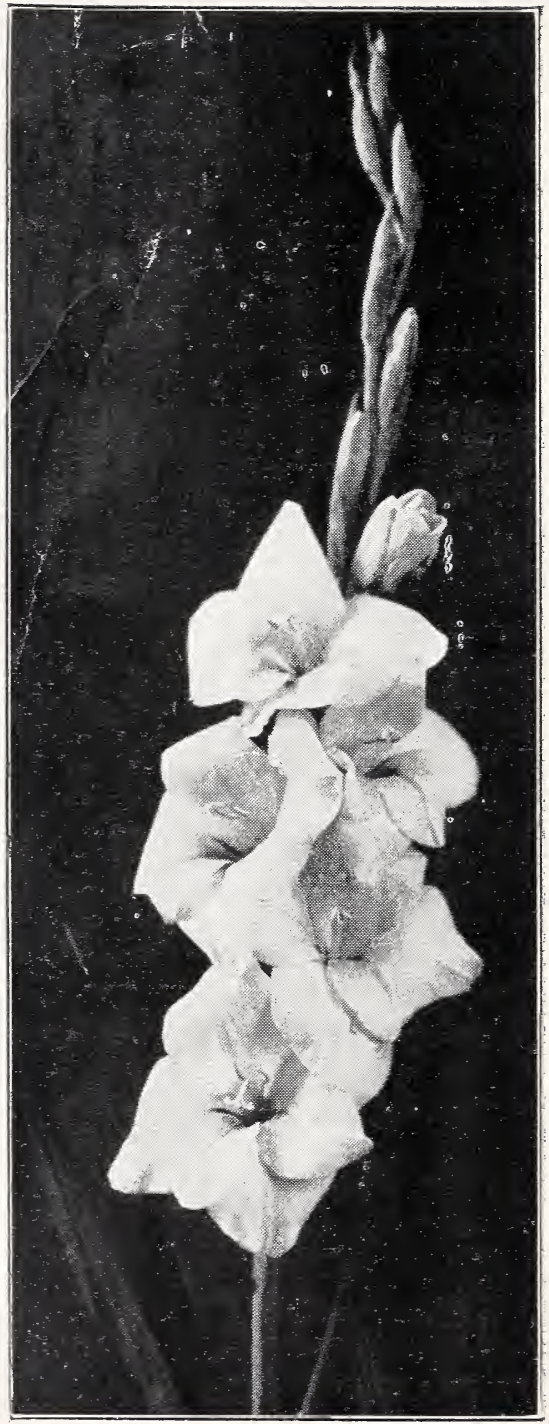

Elora, originated by Luther Burbank 